\title{
Assessment of the myelin damage degree in patients with and without diabetic neuropathy
}

Authors Kostitska Iryna Oleksandrivna

Hospital Ivano-Frankivsk National Medical University, endocrinology department

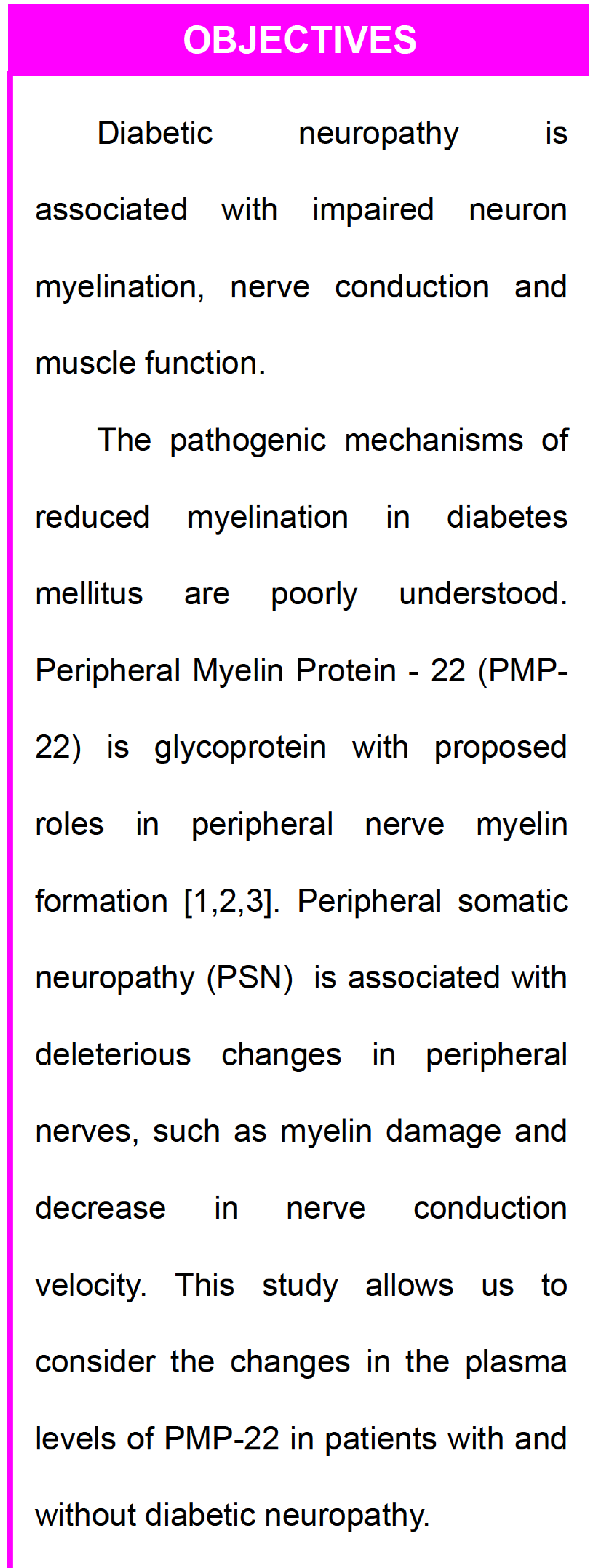

\section{CONCLUSIONS}

These findings could suggest the occurrence of the neuron demyelination reflected by the elevated $\mathrm{PMP}-22$ in patients with diabetic neuropathy.

\section{METHODS}

We studied 34 subjects with DM duration of $15.2 \pm 2.1$ years, mean value of $\mathrm{HbA} 1 \mathrm{C}$ was $8.4 \pm 1.2 \%$ divided into 2 groups: diabetic patients without symptoms of PSN (consisted of 12 participants ( 5 male/7 female), mean age was $42.7 \pm 10.1$ years) and patients with diabetes and confirmed diagnosis of diabetic PSN (22 patients (8 male/14 female), mean age was $42.8 \pm 10.1$ years) and 20 healthy volunteers ( 9 male/11 female, mean age was $48.3 \pm 9.5$ years) as the control group. The plasma concentrations of PMP-22 were measured by immunoassay. No subjects studied had signs of other disorders of peripheral nervous system.

\section{RESULTS}

We found that plasma levels of PMP-22 were significantly higher in the patients with PSN $(9.1 \pm 1.32 \mathrm{ng} / \mathrm{ml})$ compared to diabetic subjects without PSN (3.8 $\pm 0.15 \mathrm{ng} / \mathrm{ml})$ and control group $(1.53 \pm 0.31 \mathrm{ng} / \mathrm{ml}), \mathrm{p}<0.05$

\section{References}

1.Peripheral myelin protein 22 is expressed in human central nervous system / Y. Ohsawa, T. Murakami, Miyazaki Y [et al.] // J. Neurol Sci. 2006. - Vol. 15. -№ 247(1). - P.11-15.

2.Peripheral myelin protein 22 is in complex with alpha6beta4 integrin, and its absence alters the Schwann cell basal lamina/ S.A. Amici, W.A. Dunn, Jr.Murphy et al. // J. Neurosci. - 2006. -№ 26 (4). - P.1179-1189.

3.Rickey E.C. Modeling nerve conduction criteria for diagnosis of diabetic polyneuropathy / E.C. Rickey, J. William // Muscle and Nerve. - 2011. Vol. 44. - P. 340-345. 